\title{
SWIM TRAINING REVERSES SOME EFFECTS OF NANDROLONE DECANOATE IN WISTAR RATS
}

TREINAMENTO DE NATAÇÃO REVERTE ALGUNSEFEITOS DO DECANOATO DE NANDROLONA EM ORIGINAL ARTICLE RATOS WISTAR

\section{EL ENTRENAMIENTO EN NATACIÓN REVIERTE ALGUNOS EFECTOS DEL DECANOATO DE NANDROLONA EN LOS RATONES WISTAR}

Lilian Cristina Gomes do

Nascimento ${ }^{1}$ (iD

(Physical Therapist)

José Martins Juliano Eustaquio 1,2 (ID (Sports Physician)

Laís Pereira Mendes ${ }^{2}$ (D)

(Medical Student)

Rodrigo Otávio dos Santos ${ }^{1}$ (ID (Physical Education Professional) Octávio Barbosa Neto' (ID (Physical Education Professional)

1. Universidade Federal do Triângulo Mineiro, Postgraduate Program in Physical Education, Human Performance and Sports Research Group, Uberaba, MG, Brazil.

2. Universidade de Uberaba, Hospital Mário Palmério, Uberaba, MG, Brazil.

\section{Correspondence:}

Octávio Barbosa Neto. Grupo de Pesquisa em Performance Humana e Esporte, Programa de PósGraduação em Educação Física, Universidade Federal do Triângulo Mineiro. Av. Tutunas, 490, Uberaba, Brasil. 38061-500.

octavio.neto@uftm.edu.br zemartinsjuliano@hotmail.com

\begin{abstract}
Introduction: The indiscriminate use of androgenic steroids may have deleterious effects on human tissue. Objectives: Evaluate the effects of chronic administration of the steroid nandrolone decanoate (DECA) on autonomic cardiovascular modulation, kidney morphometry and the association between these variables in Wistar rats subjected to physical training with swimming. Methods: Thirty-two male Wistar rats aged 20 weeks were distributed among four experimental groups according to the training received: sedentary control (SC), sedentary treated with DECA (SD), trained control (TC) and trained treated with DECA (TD). The hemodynamic parameters, including blood pressure and variations in systolic blood pressure (SBPV) and diastolic blood pressure (DBPV), and kidney morphometry were evaluated. The level of significance adopted was $5 \%$. Results: The SD group had higher baseline SBP and DBP values when compared to the SC, TC and TD groups, which were similar to each other. The rats in the SD group had higher systolic blood pressure (SBPV) and diastolic blood pressure (DBPV) variation values and higher absolute and normalized values in the LF band of the DBPV when compared to the animals in the SC, TC and TD groups. The animals in the SD group had a significantly higher rate of kidney fibrosis compared to the SC,TC and TD groups. There were no significant differences between the sympathetic modulation of SBPV through the LF component and kidney fibrosis. Conclusions: Physical training with swimming was effective in preventing the increase in blood pressure levels and lowering the occurrence of kidney fibrosis in animals treated with anabolic steroids. Level of Evidence IV; Series of cases.
\end{abstract}

Keywords: Sympathetic nervous system; Sports medicine; Cardiovascular system; Heart rate.

\section{RESUMO}

Introdução: O uso indiscriminado de esteroides androgênicos pode ter consequências deletérias no organismo. Objetivo: Avaliar os efeitos da administração crônica do esteroide decanoato de nandrolona (DECA) em ratos Wistar submetidos a treinamento físico com natação sobre a modulação autônoma cardiovascular, morfometria renal e associação entre essas variáveis. Métodos: Foram utilizados 32 ratos Wistar machos com idade de 20 semanas, distribuidos em 4 grupos experimentais de acordo com o tratamento recebido: sedentários controles (SC), sedentários que receberam o DECA (SD), treinados controles (TC) e treinados que receberam o DECA (TD). Avaliaram-se parâmetros hemodinâmicos, como pressão arterial e variação da pressão arterial sistólica (VPAS) e diastólica (VPAD) e morfometria renal. O nivel de significância adotado foi de 5\%. Resultados: O grupo SD apresentou valores basais maiores de PAS e PAD quando comparado aos grupos SC, TC e TD, os quais foram semelhantes entre si. Os animais do grupo $S D$ tiveram valores maiores da variância da VPAS e VPAD e valores absolutos maiores e normalizados da banda LF da VPAD, em comparação com os animais dos grupos SC, TC e TD. O grupo SD teve taxa significativamente maior de fibrose renal em comparação com os animais dos grupos SC, TC e TD. Não se evidenciaram diferenças consideráveis entre a modulação simpática da VPAS através do componente LF e fibrose renal. Conclusões: O treinamento físico com natação foi efetivo em prevenir o aumento de níveis pressóricos e diminuir a ocorrência de fibrose renal em animais tratados com esteroide anabolizante. Nível de Evidência IV; Série de casos.

Descritores: Sistema nervoso simpático; Medicina esportiva; Sistema cardiovascular; Frequência cardíaca.

\section{RESUMEN}

Introducción: El uso indiscriminado de esteroides androgénicos puede tener consecuencias nocivas para el organismo. Objetivo: Evaluar los efectos de la administración crónica del esteroide decanoato de nandrolona (DECA) en ratones Wistar sometidos a entrenamiento físico con natación, sobre la modulación autonómica cardiovascular, morfometría renal y asociación entre esas variables. Métodos: Fueron utilizados 32 ratones Wistar machos con edad de 20 semanas, distribuidos en 4 grupos experimentales de acuerdo con el tratamiento recibido: sedentarios controles (SC), sedentarios que recibieron el DECA (SD), entrenados controles (EC) y entrenados que recibieron el DECA (ED). Se evaluaron parámetros hemodinámicos, como presión arterial y variación de la presión arterial sistólica (VPAS) y diastólica (VPAD) y morfometría renal. 
El nivel de significancia adoptado fue de 5\%. Resultados: El grupo SD presentó valores basales mayores de PAS y PAD cuando comparados a los grupos SC, EC Y ED, los cuales fueron semejantes entre sí. Los animales del grupo SD tuvieron valores mayores de la variancia de VPAS Y VPAD y valores absolutos mayores y normalizados de la banda LF de la VPAD, en comparación con los animales de los grupos SC, EC y ED. El grupo SD tuvo tasa significativamente mayor de fibrosis renal en comparación con los animales de los grupos SC, EC y ED. No se evidenciaron diferencias considerables entre la modulación simpática de la VPAS a través del componente LF y fibrosis renal. Conclusiones: El entrenamiento fisico con natación fue efectivo en prevenir el aumento de niveles presóricos y disminuir la ocurrencia de fibrosis renal en animales tratados con esteroide anabolizante. Nivel de Evidencia IV; Serie de casos.

\section{Descriptores: Sistema nervioso simpático; Medicina deportiva; Sistema cardiovascular; Frecuencia cardíaca.}

\section{INTRODUCTION}

Several physiological adaptations are induced by physical training (PT), which can develop within the first days of training (short time adaptations), within the following months (medium time adaptations) or even take years for such adaptations to develop (long time adaptation). $1,2 \mathrm{Above}$ all, is worth mentioning that these changes do not happen the same way in all individuals, factors such as biological individuality and the kind of exercise chosen, among others aspects, may cause divergent responses. ${ }^{3,4}$

In order to obtain body image satisfaction and improve physical performance, many individuals are attracted to the consumption of ergogenic resources, for example anabolic androgenic steroids (AAS). One of the objectives of AAS is acceleration of the processes of muscle mass growth and strength gain. ${ }^{5,6}$

Despite the positives effects related to muscle mass gain and physical performance improvement, the indiscriminate use of AAS can also induce harmful changes to the body, including cardiac, ${ }^{7}$ autonomic, $^{8}$ metabolic dysfunctions, ${ }^{9}$ among others.

One of the most globally used AAS is nandrolone decanoate (DECA),

${ }^{10}$ due to its moderate androgenic potential and good anabolic properties, ${ }^{11,12}$ the injectable form is most commonly used.

Currently, there is no consensus in the literature about the effects of chronic AAS administration on kidney morphometry and its association with cardiovascular autonomic modulation in experimental models, as well the effects of physical swimming training on such alterations.

\section{MATERIALS AND METHODS}

In the present study, we used 34 male Wistar rats (Rattusnorvegicus, var. Albinus), paired by weight and age, at 20 weeks of age. The animals were kept in collective cages (four animals per cage - ZOOTECH 375), with control of the ambient temperature of $22^{\circ} \mathrm{C}\left( \pm 1^{\circ} \mathrm{C}\right)$, humidity of 40-70\%, photoperiod of 12 hours (light / dark) and with free access to water and feeds (Nuvilab CR1, NuvitalNutrientesLtda, Curitiba, PR). This study was submitted and approved by the Ethics Committee on the Use of Animals at the Universidade Federal do Triângulo Mineiro (UFTM), under protocol number 202.

The animals were randomly distributed to four experimental groups, according to the treatment, received, and divided into sedentary control (SC), sedentary treated with AAS (SD), trained control (TC) and trained treated with AAS (TD).

The steroid used was DECA (Deca-Durabolin ${ }^{\oplus}$, Organon, Brazil), with doses administered once a week, via intramuscular injections at a dose of $5 \mathrm{mg} / \mathrm{kg}$ from the beginning of the physical training protocol. We injected equal volumes of peanut oil in the same way into control animals. The time of use of AAS and peanut oil were equivalent to the time of the swimming protocol.

\section{Training Protocol}

The animals in the trained groups were submitted to swimming sessions in a tank measuring $100 \mathrm{~cm} \times 50 \mathrm{~cm} \times 60 \mathrm{~cm}$, containing water heated to $30^{\circ} \mathrm{C}\left( \pm 2^{\circ} \mathrm{C}\right)$ to a depth of $45 \mathrm{~cm}, 5$ times a week during the period for 8 weeks. The protocol consisted of a week of training for adaptation, which started with 10 minutes of training and there was a daily increase until reaching 50 minutes, without overload (ie.without any weight attached to the tail]. From the second week onwards, the daily training time became 60 minutes and there was a weekly increase of 1\% overload (with weights attached to the tail representing $1 \%$ of body mass) until reaching $5 \%$ overload. During the sixth, seventh and eighth weeks of training, it consisted of 60 minutes of training with $5 \%$ of body overload. ${ }^{13}$

The sedentary animals were placed in the swimming tank and remained there for a period of 2 minutes, twice a week, to evaluate the effect of physical training and to ensure that the changes were not due to possible aquatic stress.

\section{Evaluation Protocol}

One day after the last training session, all animals were anesthetized with thiobarbital (40 mg / kg, i.p.) and polyethylene catheters (PE-10 fused to an extension of PE-50; Clay Adams Brand, Polvethylene Tubing , Becton Dickinson, Sparks) filled with saline were then introduced into the left femoral artery for direct blood pressure (BP) recording. The catheters were externalized to the dorsal region of the rats. Immediately after the surgical procedure, all animals received subcutaneous injection, $2 \mathrm{mg}$ / kg of the analgesic butorphanoll, repeated of administration every 4 hours until 8 hours before commencing recordings.

After 24 hours of surgical recovery, the arterial catheter was connected to a BP transducer and a signal amplifier (Model 8805A, Hewlett-Packard, USA), where the signal was converted by an analogue-digital plate (with sampling frequency $-1000 \mathrm{~Hz}$ ), transferred to a computerized data acquisition system (Aqdados, LynxTec. Eletron. SA, São Paulo, Brazil) and then stored on a computer, for later analysis.

The animals remained in individual cages in a room with a quiet environment, with minimum noise and a restricted flow of people, at a temperature of $27^{\circ} \mathrm{C}$ for an adaptation period of 15 minutes. Continuous records of pulsatile BP were performed for 30 minutes to obtaining baseline BP values and thereby allowing the assessment of blood pressure variation (BPV) in the time domain (variance) and in the frequency domain (spectral analysis).

The BP signal, continuously recorded throughout the protocol, was processed by software (PRE 24), kindly provided by Professor Eng. Alberto Porta of the University of Milan, Italy, in order to generate beat-to-beat pulse intervals (PI). The variability of $\mathrm{PI}$, systolic blood pressure (SBP) and diastolic blood pressure (DBP) was also assessed in the frequency domain (FD), using the autoregressive spectral analysis method. ${ }^{14,15}$ The spectral parameters obtained for each individual stationary segment of 
300 beats were measured and resulting average values for the baseline 30 minutes were collected for each animal.

After performing the experimental protocols, all animals were anesthetized with thiobarbital (40 mg / kg, intraperitoneally), and then euthanized with the administration of potassium chloride. Immediately after euthanasia, the left kidney of each animal was excised, fixed in $10 \%$ formaldehyde and the kidneys cut longitudinally. The organs were subjected to dehydration process in an increasing series of ethyl alcohol (70\%, 95\% and absolute). Subsequently, the kidneys were transferred to xylol (I, II and III) for diafinization of the material, which was then impregnated in paraffin at $60^{\circ} \mathrm{C}$ for 2 hours and the slides were cut, finished with picrosirius stains (for analysis of cardiac (renal?) fibrosis and details of interstitial fibrosis).

Under 20x magnification of the microscopic analyses of the entire tissue sections were quantified. This analysis was performed from the images of the histological sections that were captured by a digital system, through the capture of the images by an AxioCam ICc1 video camera coupled to a Scope A1 microscope. The captured images were sent to an analyzer system, visualized on a monitor and recorded for morphometric analysis in the ImageJ program (ImageProPlus software), previously calibrated before any image analysis, adapting the calibration according to the lens size used.

\section{Statistical Analysis}

The comparation of hemodynamic parameters and kidney morphometry between groups was undertaken using the one-way analysis of variance (ANOVA) test followed by Tukey's post-hoc test. Pearson's correlation test was used to analyze the association between DECA, autonomic modulation and morphological parameters. All data evaluated were expressed as mean \pm standard error of the mean ( \pm SEM). The level of significance accepted was 5\% ( $p<0.05)$. The analyzes were conducted using the SigmaStat 8.0 software (JandelScientific Software; SPSS, Chicago, IL).

\section{RESULTS}

Regarding baseline SBP values, there were no significant differences between animals in the SC (120.70 $\pm 1.90 \mathrm{mmHg}), \mathrm{TC}(121.71 \pm 2.38$ $\mathrm{mmHg})$ and TD $(122.45 \pm 3.91 \mathrm{mmHg})$ groups. Sedentary animals that were treated with DECA, however, had higher SBP values (127.67 \pm 1.51 $\mathrm{mmHg}$ ) compared to $\mathrm{SC}(\mathrm{p}<0.05)$. Regarding the results of baseline DBP values, was observed that the patterns followed were similar to that of SBP. There were no significant differences between the SC $(90.25 \pm 1.99$ $\mathrm{m}), \mathrm{TC}(90.12 \pm 29 \mathrm{mmHg})$ and TD $(89.71 \pm 2.32 \mathrm{mmHg})$ groups, however, SD animals showed high levels of DBP $(100.35 \pm 1.95 \mathrm{mmHg})$ compared to animals in the SC group ( $p<0.05)$.

Concerning the BPV data, the animals in the SD group showed higher values of the variance of the SBP (SBPV) and of the DBP (DBPV) and higher absolute and normalized values of the low frequency band (LF) of the DBPV, compared to the SC, TC and TD animals (Table 1). The TC group presented a higher variance of SBPV when compared to the SC group. The animals in the SD and TC groups presented higher absolute values of the LF component of the SBPV than the SC animals. The TD animals showed lower DBP variance than their respective sedentary group, however, they showed higher variance in relation to SC and TC animals (Table 1).

Regarding kidney morphometry, it was found that the SD animals presented a significantly higher rate of renal fibrosis (2.13 $\pm 0.09 \%)$ compared to animals in the SC (1.59 $\pm 0.30 \% ; p<0.05), \mathrm{TC}(1.54 \pm 0.34$; $p<0.05)$ and TD $(1.72 \pm 0.07 ; p<0.05)$ groups. When correlating any association between the sympathetic modulation of PASV through the low frequency band (LF) component and the presence of renal fibrosis, there were no significant differences (Figure 1).
Table 1. Value of mens ( \pm SEM) of the components of SBP and DBP in the animals domains of time and frequency.

\begin{tabular}{c|c|c|c|c}
\hline & $\begin{array}{c}\text { SC } \\
(\mathbf{n = 0 8})\end{array}$ & $\begin{array}{c}\text { SD } \\
(\mathbf{n = 0 8})\end{array}$ & $\begin{array}{c}\text { TC } \\
(\mathbf{n = 0 8})\end{array}$ & $\begin{array}{c}\text { TD } \\
(\mathbf{n}=\mathbf{0 8})\end{array}$ \\
\hline VPAS & & & & \\
\hline Variância $\left(\mathrm{mmHg}^{2}\right)$ & $14.4 \pm 1.2$ & $24.7 \pm 2.6^{*}$ & $20.7 \pm 2.7^{*} \dagger$ & $21.1 \pm 2.5 \dagger$ \\
\hline LF $\left(\mathrm{mmHg}^{2}\right)$ & $4.1 \pm 0.9$ & $6.7 \pm 0.5^{*}$ & $5.5 \pm 0.3^{*}$ & $5.4 \pm 0.6$ \\
\hline LF $(\mathrm{nu})$ & $47.0 \pm 5.1$ & $56.9 \pm 3.8$ & $44.6 \pm 3.6$ & $46.4 \pm 3.0$ \\
\hline VPAD & & & & \\
\hline Variância $\left(\mathrm{mmHg}^{2}\right)$ & $9.8 \pm 0.2$ & $22.3 \pm 1.2^{*}$ & $12.6 \pm 1.9 \dagger$ & $18.2 \pm 0.9^{*}+\#$ \\
\hline LF $(\mathrm{mmHg})$ & $5.0 \pm 0.3$ & $8.0 \pm 0.5^{*}$ & $4.4 \pm 0.8 \dagger$ & $5.0 \pm 0.2 \dagger$ \\
\hline LF $(\mathrm{nu})$ & $48.0 \pm 1.5$ & $60.3 \pm 1.6^{*}$ & $46.1 \pm 0.9 \dagger$ & $47.8 \pm 1.4 \dagger$ \\
\hline
\end{tabular}

SC: sedentary control:SD: sedentary treated with DECA:TC: trained control:TD trained treated with DECA. LF - low frequency band. nu - normalized units. ${ }^{*} p<0,05 v s . S C,{ }^{\dagger} p<0,05$ vs. SD, ${ }^{p} p<0,05$ vs. TC.

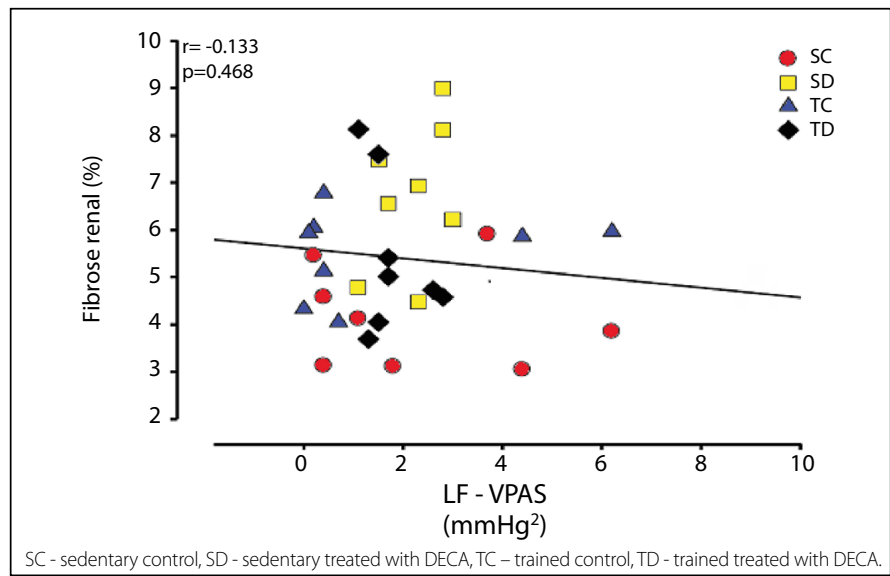

Figure 1. Correlation coefficient between sympathetic modulation of systolic blood pressure variability (VSBP) and renal fibrosis (\% RF) of animals.

\section{DISCUSSION}

The current study demonstrated that sedentary animals chronically treated with AAS had higher blood pressure levels compared to control animals, both from SBP and DBP. The literature documents that, in the medium term, the use of AAS is associated with increases in DBP and mean arterial blood pressure (MBP), which returns to baseline values after the suspension of $\mathrm{AAS}^{16}$, both in animals ${ }^{17}$ and in human athletes. ${ }^{18,19}$

In contrast to the results found in our study, some studies have shown conflicting results, with maintenance of blood pressure level ${ }^{20}$ or even decrease in BP after the use of AAS. 21,22 Such discrepancies are very common in the literature when it comes to AAS and pressure responses, and these differences can be explained by the use of different measurements of AAS and / or by the use of different study protocols.

The lack of adaptation in the BP response to physical training in normotensive rats is well established and documented in the literature, 23,24 which is in line with our results, where no significant differences were found in the BP of trained rats. In fact, physical training is well-recommended as a non-pharmacological treatment for hypertensive patients, 25,26 however, its effect on normotensive targets (experimental or human animal models) seems to be minimal. 24,26

In humans, there is sometimes an increase in cardiac vagal activity after physical training. ${ }^{26,27}$ Animals submitted to physical training also demonstrated an increase in vagal activity. ${ }^{23}$ With physical activity, there is an increase in nitric oxide bioavailability, including in central mechanisms. ${ }^{24}$ This is a pathway that relates to the maintenance of parasympathetic activity in trained animals administered with AAS.

In this study, the animals that received AAS had a higher BPV compared to the animals in the control group, but with attenuation of variability after physical training. Some findings in the literature demonstrate a relationship between increased BPV with progression of cardiovascular 
diseases and sudden deaths. ${ }^{28}$ However, due to the difficulties in BP recording and variations in BP throughout the day, these data are still controversial. This increase may relate to impaired baroreflex sensitivity, but further investigations are necessary regarding this subject.

It was also demonstrated that the rats chronically treated with AAS had a higher percentage of renal fibrosis, however a simple physical training protocol with swimming was effective in preventing this condition. Some researchers have shown that kidney functional and structural changes can develop in response to changes in sympathetic nerve activity. ${ }^{29,30}$

The renal system has a dense afferent and efferent sympathetic innervation. ${ }^{29}$ Constant sympathetic activation contributes to an aggravating condition of arterial hypertension that can initiate a renal injury. If sympathetic activation is a fundamental process in chronic kidney failure, this may infer that inhibition of the adrenergic pathway can antagonize the process of kidney damage. This simple fact could explain the association between sympathetic decrease and the attenuation of renal fibrosis rates found in our study, mainly in relation to the effects of physical swimming training.
Chronic physical exercise has been reported to attenuate segmental and focal glomerulosclerosis, and this decrease has been associated with less sympathetic nervous activity and consequently reduced of $\mathrm{BP} .{ }^{30}$

Despite the fact that countless investigators have provided data on the harmful effects of using AAS on the renal system, ${ }^{711}$ the exact pathophysiology through the use of these substances is still unknown, requiring further investigation.

\section{CONCLUSION}

Chronic administration of DECA induces significant renal fibrosis, increased SBP and DBP and altered blood pressure modulation in Wistar rats. However, the physical training of swimming can be an efficient model for the mitigation of side-harms caused by chronic use of AAS in Wistar rats.

All authors declare no potential conflict of interest related to this article

AUTHORS' CONTRIBUTIONS: Each author made significant individual contributions to this manuscript.. LCGN: writing, review, and performing the evaluations; JMJE: data analysis and writing; LPM: statistical analysis and bibliographical review; ROS: intellectual concept, review and performing the evaluations; OBN: writing, review and elaboration of the entire research project. All authors reviewed and approved the final version of the manuscript.

\section{REFERENCES}

1. Midgley AW, McNaughton LR, Wilkinson M. Is there an optimal training intensity for enhancing the maximal oxygen uptake of distance runners?: empirical research findings, current opinions, physiological rationale and practical recommendations. Sports Med. 2006;36(2):117-32

2. Rivera-Brown AM, Frontera WR. Principles of exercise physiology: responses to acute exercise and long-term adaptations to training. Principles Exerc Physiol. 2012;4(11):797-804.

3. Maclnnis MJ, Gibala MJ. Physiological adaptations to interval training and the role of exercise intensity. J. Physiol. 2017;595(9):2915-30.

4. Sousa DF, Eustaquio JMJ, Marocolo M, Mota GR, Barbosa Neto O. Alterações autonômicas cardíacas em diferentes perfis táticos do Jiu Jitsu Brasileiro. Rev Bras Med Esporte. 2020;26(3):196-200.

5. Pope Jr HG, Khalsa JH, Bhasin S. Body image disorders and abuse of anabolic-androgenic steroids among men. JAMA. 2017;317(1):23-4.

6. Kanayama G, Pope HG Jr. History and epidemiology of anabolic androgens in athletes and nonathletes. Mol Cell Endocrinol. 2018;464:4-13.

7. Germanakis I, Tsarouhas K, Fragkiadaki P, Tsitsimpikou C, Goutzourelas N, Champsas MC, et al. Oxidative stress and myocardial dysfunction in young rabbits after short term anabolic steroids administration. Food Chem Toxicol. 2013;61:101-5.

8. Santos MR, Sayegh AL, Armani R, Costa-Hong V, Souza FR, Toschi-Dias E, et al. Resting spontaneous baroreflex sensitivity and cardiac autonomic control in anabolic-androgenic steroid users. Clinics. 2018;73:e226.

9. Pinheiro JL, Maia BP, Lima AB, Domingues RJS, Oliveira FRT, Freitas JJS, et al. Nandrolone decanoate is prooxidant in the myocardium of exercised or sedentary rats. Rev Bras Med Esporte. 2020;26 (1):16-20.

10. Aldarweesh HH, Alhajjaj AH. Anabolic Androgenic Steroid Use Prevalence, Knowledge, and Practice Among Male Athletes in Eastern Province of Saudi Arabia. Electron J Gen Med. 2020;17(2):em187.

11. Abrahin OSC, Sousa EC. Esteroides anabolizantes androgênicos e seus efeitos colaterais: uma revisão crítico-científica. Revi Educ Fís. 2013;24(4):669-79.

12. Barone R, Pitruzzella A, Marino Gammazza A, Rappa F, Salerno M, Barone F, et al. Nandrolone decanoate interferes with testosterone biosynthesis altering blood-testis barrier components. J Cell Mol Med. 2017;21(8):1636-47.

13. Lancha AH Jr, Recco MB, Abdalla DS, Curi R. Effect of aspartate, aspargine and carnitine supplementation in the diet on metabolismo of skeletal muscle during a moderate exercise. Physiol Behav. 1995;57(2):367-71.

14. Malliani A, Pagani M, Lombardi F, Furlan R, Guzzetti S, Cerutti S. Spectral analysis to assess increased sympathetic tone in arterial hypertension. Hypertension. 1991;17(4 Suppl):III36-42.

15. Malik JM, Bigger AT, Camm J, Kleiger RE, Malliani A, Moss AJ, et al. Heart rate variability: Standards of measurement, physiological interpretation, and clinical use. European Heart Journal. 1996;17(3):354-81.

16. Grace F, Sculpthorne N, Baker J, Davies B. Blood pressure and rate pressure response in males using high-dose anabolic androgenic steroids (AAS). J Sci Med Sport. 2003;6(3):307-12.
17. Roşca AE, Stoian I, Badiu C, Gaman L, Popescu BO, losif L, et al. Impact of chronic administration of anabolic androgenic steroids and taurine on blood pressure in rats. Braz J Med Biol Res. 2016;49(6):e5116

18. Barton M, Prossnitz ER, Meyer MR. Testosterone and secondary hypertension: new pieces to the puzzle. Hypertension. 2012;59(6):1101-3.

19. Andrews MA, Magee CD, Combest TM, Allard RJ, Douglas KM. Physical Effects of Anabolic-androgenic Steroids in Healthy Exercising Adults: A Systematic Review and Meta-analysis. Curr Sports Med Rep. 2018;17(7):232-41.

20. Koike DC. Efeitos do treinamento físico no balanço autonômico e parâmetros cardiovasculares de ratos submetidos ao uso de esteroides anabólicos. 2009. Dissertação (Mestrado em Educação Física), Universidade São Judas Tadeu, São Paulo. 46p.

21. Perusquía M, Greenway CD, Perkins LM, Stallone JN. Systemic hypotensive effects of testosterone are androgen structure-specific and neuronal nitric oxide synthase-dependent. Am J Physiol Regul Integr Comp Physiol. 2015;309(2):R189-95.

22. Perusquía M, Herrera N, Ferrer M, Stallone JN. Antihypertensive effects of androgens in conscious, spontaneously hypertensive rats. J Steroid Biochem Mol Biol. 2017;167:106-14.

23. Krieger EM, Brum PC, Negrao CE. Role of arterial baroreceptor function on cardiovascular adjustments to acute and chronic dynamic exercise. Biol Res. 1998;31(3):273-9.

24. Jakovljevic B, Turnic TN, Jeremic N, Jeremic J, Bradic J, Ravic M, et al. The impact of aerobic and anaerobic training regimes on blood pressure in normotensive and hypertensive rats: focus on redox changes. Mol Cell Biochem. 2019;454(1-2):111-121.

25. Ruangthai R, Phoemsapthawee J. Combined exercise training improves blood pressure and antioxidant capacity in elderly individuals with hypertension. J Exerc Sci Fit. 2019;17(2):67-76.

26. Bersaoui M, Baldew SM, Cornelis N, Toelsie J, Cornelissen VA. The effect of exercise training on blood pressure in African and Asian populations: A systematic review and meta-analysis of randomized controlled trials. Eur J Prev Cardiol. 2020;27(5):457-72.

27. Bhati P, Moiz JA, Menon GR, Hussain ME. Does resistance training modulate cardiac autonomic control? A systematic review and meta-analysis. Clin Auton Res. 2018;29(1):75-103.

28. Stevens SL, Wood S, Koshiaris C, Law K, Glasziou P, Stevens RJ, et al. Blood pressure variability and cardiovascular disease: systematic review and meta-analysis. BMJ. 2016;354:14098.

29. Thompson S, Wiebe N, Padwal RS, Gyenes G, Headley SAE, Radhakrishnan J, et al. The effect of exercise on blood pressure in chronic kidney disease: A systematic review and meta-analysis of randomized controlled trials. PLoS ONE. 2019;14(2):e0211032.

30. Barbosa Neto O, Abate DT, Marocolo Júnior M, Mota GR, Orsatti FL, Silva RCR, et al. Exercise training improves cardiovascular autonomic activity and attenuates renal damage in spontaneously hypertensive rats. J Sports Sci Med. 2013;12(1):52-9. 